\title{
Effect of Foliar Fungicides on Corn with Simulated Hail Damage
}

\author{
C. A. Bradley and K. A. Ames, Department of Crop Sciences, University of Illinois, Urbana 61801
}

\begin{abstract}
Bradley, C. A., and Ames, K. A. 2010. Effect of foliar fungicides on corn with simulated hail damage. Plant Dis. 94:83-86.

Quinone outside inhibitor (QoI) foliar fungicides can be effective at reducing foliar diseases in corn (Zea mays), and they have been shown to provide physiological benefits experimentally in other crops in the absence of disease. A new supplemental label for pyraclostrobin that was approved in January 2009 by the United States Environmental Protection Agency (EPA) states that corn plants applied with pyraclostrobin may have better tolerance to damage caused by hail. To determine the effects of QoI foliar fungicides on hail-damaged corn, field research trials were conducted near Champaign, IL in 2007 and 2008. Hail damage was simulated with a gasolinepowered string-mower at the V12 growth stage, which caused injury to leaves and defoliation. At VT, the foliar fungicides azoxystrobin and pyraclostrobin were applied to corn. Control treatments included a nontreated control and a nondamaged control. The simulated hail damage significantly $(P \leq 0.05)$ increased gray leaf spot severity (caused by Cercospora zeae-maydis) in 2007 but not in 2008. Simulated hail damage also significantly reduced yield compared with the nondamaged control in both 2007 and 2008. Foliar fungicides significantly reduced disease severity compared with the nontreated control in 2007 but not in 2008; however, foliar fungicides did not significantly improve yield in either the damaged or nondamaged plots compared with the nontreated controls. Results from our research trials indicated that foliar fungicides provided very little benefit to corn injured by simulated hail; thus, growers should consider factors other than hail damage when making fungicide application decisions for corn.
\end{abstract}

Prior to 2007, application of foliar fungicides to hybrid corn (Zea mays) in the Midwest was rare to very sporadic but, in 2007, estimates of approximately 4.3 to 5.6 million ha out of an approximate total of 30.8 million ha of corn in the Midwest were sprayed with a foliar fungicide (13). This dramatic increase in foliar fungicide use in corn production was brought on by many different factors. One of these factors was that corn market prices reached unprecedented levels in 2007. With high market prices for corn, the yield response needed to pay for a fungicide application was lowered, which made this practice more enticing to corn growers. Another factor was that some agrichemical companies were marketing and promoting fungicide applications at the VT growth stage (5) for yield enhancement due to improved growth efficiency and stress tolerance, in addition to disease control. Physiological effects of quinone outside inhibitor (QoI) fungicides on plants in greenhouse and laboratory studies such as delaying senescence, altering amounts of plant hormones, increasing activity of antioxidative enzymes, and increasing activity of nitrate reductase have been reported $(7-9,19,26-$

Corresponding author: C. A. Bradley

E-mail: carlbrad@illinois.edu

Accepted for publication 15 September 2009.

doi:10.1094/PDIS-94-1-0083

(C) 2010 The American Phytopathological Society
28). The possibility of yield enhancement without regard to disease pressure was enough of a reason for some corn growers to plan for using a foliar fungicide on their corn crops in 2007.

Damage to corn due to hail is a serious problem and occurs every year, and annual economic losses to corn growers in the United States due to hail damage ranged from approximately $\$ 36$ million to $\$ 59$ million from 2003 to 2007 (M. Zarnstorff, National Crop Insurance Services, personal communication). Both yield and quality losses can occur from hail damage in corn grown as a grain crop or forage crop (10-12,18,20,21). A hail damage chart used by the U.S. crop insurance industry estimates that yield losses on corn due to hail damage can range from 0 to $100 \%$ depending on the crop growth stage and the amount of leaf area destroyed, with the greatest yield losses occurring as the crop approaches tasseling and pollination (15).

Late in 2008, the United States Environmental Protection Agency (EPA) granted a supplemental label registration for use of Headline fungicide (pyraclostrobin; BASF Corp., Research Triangle Park, NC) on registered crops for disease control and plant health (2). Among other things, this supplemental label states that the fungicide can provide a benefit of "better tolerance to hail" in corn.

The objectives of this research were to evaluate the effect of two different QoI fungicides on hybrid corn with simulated hail damage, and to determine the effect of simulated hail damage on foliar diseases of corn under natural disease pressure.

\section{MATERIALS AND METHODS}

Field trials were conducted at the University of Illinois Crop Sciences Research and Education Center near Champaign, IL in 2007 and 2008. On 20 April 2007 and 30 May 2008, a corn hybrid (110-day maturity) with moderate susceptibility to gray leaf spot (caused by Cercospora zeaemaydis) was planted with a John Deere 7000 Max Emerge 4-row planter (Deere and Company, Moline, IL) at a seeding density of 86,450 viable seeds/ha. Plots were four rows wide ( $76 \mathrm{~cm}$ row spacings) and trimmed to $15 \mathrm{~m}$ long, with $1.2-\mathrm{m}$ wide alleys between plot ends.

When corn plants were at approximately the V12 growth stage, a simulated hail treatment was applied to half of the plots, while the other half of the plots remained nondamaged. This treatment was applied by using a handheld, gasoline-powered string mower (Ryobi Tools model no. RY34440; Ryobi Tools, Techtronic Industries Co. Ltd., Anderson, SC) to defoliate approximately 25 to $30 \%$ of the leaf area in the middle two rows of affected plots. In 2008 only, the leaf area index (LAI) of each plot was measured nondestructively 1 day following the simulated hail treatment using a LAI-2000 plant canopy analyzer (LI-COR, Inc., Lincoln, NE) to provide objective data on the amount of leaf material removed with the simulated hail damage. At the VT growth stage, plots were either treated with azoxystrobin (Quadris; Syngenta Crop Protection, Greensboro, $\mathrm{NC})$ at $109 \mathrm{~g}$ a.i./ha or pyraclostrobin (Headline; BASF Corp.) at $110 \mathrm{~g}$ a.i./ha or not treated (nontreated control). Fungicides were applied to the two middle rows of each plot with a $\mathrm{CO}_{2}$-pressurized handheld spray boom with TeeJet 60-8002 nozzle tips (Spraying Systems Co., Wheaton, IL) calibrated to deliver 187 liters/ha at $276 \mathrm{kPa}$.

Approximately 3 weeks after foliar fungicides were applied, disease severity ratings from each plot were collected. Disease severity was rated by evaluating the leaf above the ear on 10 plants/plot in the middle two rows and estimating the percent leaf area diseased; the ear leaves in the simulated hail-damaged plots generally were intact but injured. The two middle rows of each plot were harvested with a Massey Ferguson 8 research plot combine (Kincaid Equipment Manufacturing, Haven, KS) on 13 September 2007 and 27 October 2008. Grain weight and moisture 
levels were measured using a yieldmonitoring computer (HarvestMaster; Juniper Systems, Logan, UT) installed on the combine, and yields were calculated to kilograms per hectare and adjusted to $15.5 \%$ moisture.

The statistical design of the study was a three-by-two factorial (fungicide by simulated hail damage) arranged in a randomized complete block design with three and four replicated blocks in 2007 and 2008, respectively. Disease severity, yield, and seed moisture data were analyzed using the general linear model procedure (PROC GLM) in SAS (SAS Institute Inc., Cary, NC). Year was considered a random effect, whereas simulated hail and fungicide were considered fixed effects in the model. The LAI data collected in 2008 were analyzed using PROC GLM, and simulated hail was the only effect evaluated because LAI was measured prior to the fungicide applications. Means of main effects were compared using Fisher's protected least significant difference test $(\alpha=0.05)$. If significant $(P \leq$ 0.05 ) interactions were observed, then leastsquare means of the interactions were compared using PDIFF in SAS.

\section{RESULTS}

From the analysis of variance, many main effects and interactive effects were significant $(P \leq 0.05$; Table 1$)$. For disease severity, the main effects of year, hail, and the interactive effects of year-hail and year-fungicide were significant. For yield, the main effects of year and hail and the interactive effect of year-hail were significant. For seed moisture, only the main effects of year, hail, and fungicide were significant. Only results of significant effects are presented and, when a main effect significantly interacted with another main effect, only the results of the interactive effects are presented.

Significant differences in LAI between simulated hail damaged and nondamaged plots were observed in 2008, where simulated hail damaged plots had an average LAI of 2.3 compared with an average LAI of 3.2 in the nondamaged plots. Averaged over all fungicide treatments, the simulated hail damage significantly increased disease severity compared with no simulated damage in 2007 but not in 2008 (Table 2). In 2007, disease severity in the simulated hail-damaged plots was $52 \%$ compared with $44 \%$ in the nondamaged plots; however, in 2008, disease severity was the same in the simulated hail-damaged plots and the nondamaged plots $(4 \%)$. In both years, yield from simulated hail-damaged plots was reduced compared with nondamaged plots averaged over all fungicide treatments. Yields from simulated haildamaged plots were 8,762 and 7,297 kg/ha and yields from nondamaged plots were 10,728 and $10,357 \mathrm{~kg} / \mathrm{ha}$ in 2007 and 2008, respectively.

Averaged over simulated hail treatments, fungicides affected disease severity in 2007 but not in 2008 (Table 3). In 2007, both azoxystrobin and pyraclostrobin treatments provided significantly lower disease severity values compared with the nontreated control. In that year, the average disease severity value from the nontreated control plots was 59\% compared with 44 and $41 \%$ from the azoxystrobin- and pyraclostrobin-treated plots, respectively. However, in 2008, no significant differences occurred for disease severity among fungicide treatments and the nontreated control.

Fungicides did not have a significant effect on yield in either year. Seed harvested

Table 1. Partial analysis of variance table from a foliar fungicide by simulated hail damage field research trial conducted on hybrid corn near Champaign, IL in 2007 and 2008

\begin{tabular}{lcccc}
\hline & & \multicolumn{3}{c}{$\boldsymbol{P}>\boldsymbol{F}$} \\
\cline { 3 - 5 } Source of variation & $\mathbf{d f}$ & Disease severity & Yield & Seed moisture \\
\hline Block (year) & 5 & 0.2254 & 0.8340 & 0.1240 \\
Year & 1 & 0.0001 & 0.0002 & 0.0001 \\
Hail & 1 & 0.0013 & 0.0001 & 0.0290 \\
Fungicide & 2 & 0.0001 & 0.9977 & 0.0033 \\
Year $\times$ hail & 1 & 0.0023 & 0.0170 & 0.6289 \\
Year $\times$ fungicide & 2 & 0.0001 & 0.3949 & 0.8722 \\
Hail $\times$ fungicide & 2 & 0.2250 & 0.9204 & 0.8233 \\
Year $\times$ hail $\times$ fungicide & 2 & 0.1100 & 0.7229 & 0.6041 \\
\hline
\end{tabular}

${ }^{\mathrm{z}}$ Degrees of freedom.

Table 2. Effect of simulated hail damage on disease severity and corn yield near Champaign, IL in 2007 and 2008 (averaged over fungicide treatments) ${ }^{\mathrm{y}}$

\begin{tabular}{lccc}
\hline Year & Simulated hail damage & Disease severity $(\boldsymbol{\%})^{\mathbf{z}}$ & Yield (kg/ha) \\
\hline 2007 & No & $44 \mathrm{~b}$ & $10,728 \mathrm{a}$ \\
& Yes & $52 \mathrm{a}$ & $8,762 \mathrm{~b}$ \\
2008 & No & $4 \mathrm{c}$ & $10,357 \mathrm{a}$ \\
& Yes & $4 \mathrm{c}$ & $7,297 \mathrm{c}$ \\
\hline
\end{tabular}

y Values followed by the same letter are not significantly different $(P \leq 0.05)$.

${ }^{z}$ Percentage of the leaf above the ear covered with fungal foliar disease symptoms. The primary disease present each year was gray leaf spot (caused by Cercospora zeae-maydis). from fungicide-treated plots had significantly greater seed moisture compared with seed harvested from nontreated control plots averaged over years and simulated hail treatments (Table 4). The average seed moisture in seed harvested from nontreated plots was $19.5 \%$ compared with 21.2 and $21.4 \%$ in seed harvested from azoxystrobin- and pyraclostrobin-treated plots, respectively. Averaged over simulated hail treatments and fungicide treatments, seed harvested in 2007 had significantly lower moisture $(17.0 \%)$ compared with seed harvested in 2008 (23.5\%). Seed harvested from simulated hail-damaged plots had significantly lower moisture $(20.2 \%)$ than seed harvested from nondamaged plots $(21.2 \%)$.

\section{DISCUSSION}

Foliar fungicides have been used frequently on inbred corn for the production of hybrid corn seed, and this practice has been shown to be economically beneficial (24). In the United States, the application of foliar fungicides to hybrid corn has been uncommon until recently; however, many research studies have evaluated applications of foliar fungicides on hybrid corn for disease control efficacy $(3,14,16$, 22,23). Results from those studies have indicated that diseases such as common rust (caused by Puccinia sorghi), gray leaf spot, and northern leaf blight (caused by Exserohilum turcicum) can be managed effectively with foliar fungicides. Munkvold et al. (14) evaluated the probabilities of having a profitable economic net return

Table 3. Effect of foliar fungicides on disease severity near Champaign, IL in 2007 and 2008 (averaged over simulated hail treatments)

\begin{tabular}{lc}
\hline Year, fungicide & Disease severity $(\%)^{\mathbf{z}}$ \\
\hline 2007 & $59 \mathrm{a}$ \\
Nontreated control & $44 \mathrm{~b}$ \\
Azoxystrobin & $41 \mathrm{~b}$ \\
Pyraclostrobin & $4 \mathrm{c}$ \\
2008 & $5 \mathrm{c}$ \\
Nontreated control & $4 \mathrm{c}$ \\
Azoxystrobin & \\
Pyraclostrobin & \\
\hline z Percentage of the leaf above the ear covered \\
with fungal foliar disease symptoms. The \\
primary disease present each year was gray \\
leaf spot (caused by Cercospora zeae-maydis). \\
Values followed by the same letter are not \\
significantly different $(P \leq 0.05)$.
\end{tabular}

Table 4. Effect of foliar fungicides on harvested seed moisture near Champaign, IL in 2007 and 2008 (averaged over years and simulated hail treatments)

\begin{tabular}{lc}
\hline Fungicide & $\begin{array}{c}\text { Harvested seed } \\
\text { moisture }(\%)^{\mathbf{z}}\end{array}$ \\
\hline Nontreated control & $19.5 \mathrm{~b}$ \\
Azoxystrobin & $21.2 \mathrm{a}$ \\
Pyraclostrobin & $21.4 \mathrm{a}$ \\
\hline $\mathrm{z}$ Values followed by the same letter are not \\
significantly different $(P \leq 0.05)$.
\end{tabular}


with foliar fungicides on hybrid corn in Iowa and reported that the use of foliar fungicides can be profitable; however, the probability of a profitable application is strongly influenced by the susceptibility of the hybrid to foliar diseases and disease development. In fungicide studies where corn grain yields were measured, significant yield improvements with foliar fungicides were related to disease control (14,22-24).

In our trials, foliar fungicides did significantly decrease gray leaf spot severity compared with the nontreated control in 2007 but not in 2008. These two years differed in disease severity intensity and weather. Relative humidity data collected from a weather station at the University of Illinois's Willard Airport near the trial showed that, in 2007, there were more days with a maximum relative humidity of at least $95 \%$ in June (6 more days), July (1 more day), and August (2 more days) compared with 2008. One of the possible reasons why higher disease levels were observed in 2007 compared with 2008 may have been because relative humidity of at least $95 \%$ is required for C. zeae-maydis conidial germ tube growth and appressorium formation (4). Because of the low level of gray leaf spot in 2008 , foliar fungicides had no significant effect on disease that year.

No significant differences in yield were observed between foliar-fungicide-treated plots and nontreated plots in either year, despite a significant reduction in disease severity with fungicides in 2007. Although fungicides did reduce disease severity in 2007 compared with the nontreated control, disease severity levels were still relatively high in the fungicide-treated plots. These relatively high levels of disease severity in the fungicide-treated plots may have been the reason why no differences in yield were observed between the fungicide treatments and the nontreated control. In 2007, gray leaf spot lesions were already present on the leaves when fungicides were applied. Typically, QoI fungicides have the best disease control efficacy when they are applied preventively because of their effectiveness in inhibiting spore germination (1). Because disease development had already begun by the time azoxystrobin and pyraclostrobin were applied in our 2007 trial, the fungicides may not have been as effective as they would have been if applied earlier.

The simulated hail damage in our trials significantly reduced yield compared with the nondamaged control by 18.3 and $29.5 \%$ in 2007 and 2008, respectively. The yield reduction due to the simulated hail damage was greater than the estimate of yield reduction provided by the standard crop insurance industry hail damage-yield loss chart, which projected between 5 and $9 \%$ yield reduction with $30 \%$ leaf area destroyed at the V12 growth stage (15).
The amount of yield reduction due to hail damage can differ among hybrids $(10,11)$, which may partially explain why the yield reduction in our trials exceeded the expected yield reduction based on the crop insurance industry's yield loss chart.

Disease severity was increased in plots that were affected by the simulated hail damage compared with the nondamaged control plots in 2007 but not in 2008. Although statistically significant, the difference between mean disease severity values between damaged and nondamaged plots was only $8 \%$. Gray leaf spot, the primary foliar disease present in our trial in 2007, has not been reported previously to increase after hail damage. C. zeae-maydis infects corn leaves through stomata (4), and wounding caused by hail injury would not be expected to increase disease severity due to increased infections. Because the simulated hail damage increased disease severity in only 1 of the 2 years of the study, and because the increase in disease severity was relatively small, more research is needed to fully determine the impact of hail damage on gray leaf spot. Additional research is also needed to evaluate the effect of fungicide application timing as well. If gray leaf spot severity can be increased following hail damage, then it may be possible that an application of a QoI fungicide at some earlier time relative to when the hail damage occurs could provide a benefit in protection against disease.

Seed harvested from plots treated with a foliar fungicide had greater moisture than those harvested from the nontreated control plots. It is possible that foliar fungicides delayed senescence of treated plants in a manner similar to what has been reported in other plants $(8,19,26,28)$, thus delaying dry-down of the seed. No data were collected in our trials that measured senescence; however, personal observations indicated that plants treated with fungicides in 2007 had leaves that remained green for a longer period of time than leaves from nontreated plants.

Results from our research trials indicated that foliar fungicides provided very little benefit to corn injured by simulated hail. This was true in both years with contrasting disease severities. For a foliar fungicide to be recommended for application to hail-damaged corn, it is the authors' belief that factors other than hail damage should be considered. Paul and Munkvold (17) developed a risk-assessment model for gray leaf spot of corn, and found that the most important predictors of disease were the amount of corn residue on the soil surface at planting; the planting date, maturity, and gray leaf spot resistance level of the hybrid; and longitude. These criteria, rather than hail damage, should be used to make foliar fungicide application decisions for corn. Considering that QoI fungicides did not enhance yields under a low- disease-severity environment (2008), it is important to consider the above criteria in all situations, including fields not damaged by hail. The results of our research reinforce the importance of considering disease risk when making a foliar fungicide application. In our trials, foliar fungicides did not provide a yield benefit to either simulated hail-damaged corn plots or to nondamaged plots; however, it is possible that fungicides could affect other variables that we did not measure, such as mycotoxin levels in harvested grain and stalk rot. Folcher et al. (6) reported that a fungicide and insecticide combination applied to corn plants could reduce mycotoxin levels in harvested corn grain. In general, corn stalk rot severity can increase as stresses on the plant become more severe (25); thus, it is possible that stalk rot severity could be increased in hail-damaged corn. The effect of foliar fungicides on grain mycotoxin levels and stalk rot of corn should be evaluated in future research.

\section{ACKNOWLEDGMENTS}

This project was supported by the United States Department of Agriculture Cooperative State Research, Education, and Extension Service, Hatch project number ILLU-802-378. We thank J. Lang, W. Pedersen, R. Stahl, and R. Warsaw for assistance with the research trials.

\section{LITERATURE CITED}

1. Bartlett, D. W., Clough, J. M., Godwin, J. R., Hall, A. A., Hamer, M., and Parr-Dobrzanski, B. 2002. The strobilurin fungicides. Pest Manage. Sci. 58:649-662.

2. BASF Corporation. 2008. Headline Fungicide Supplemental Label NVA 2008-04-088-0327. BASF Corp., Research Triangle Park, NC.

3. Bowen, K. L., and Pedersen, W. L. 1988. Effects of propiconazole on Exserohilum turcicum in laboratory and field studies. Plant Dis. 72:847-850.

4. Carson, M. L. 1999. Gray leaf spot. Pages 2223 in: Compendium of Corn Diseases, 3rd ed D. G. White, ed. American Phytopathological Society, St. Paul, MN.

5. Elmore, R. 2000. How a corn plant develops. Iowa State Univ. Coop. Ext. Serv. Spec. Rep. 48, Ames.

6. Folcher, L., Jarry, M., Weissenberger, A., Gérault, F., Eychenne, N., Delos, M., and Regnault-Roger, C. 2009. Comparative activity of agrochemical treatments on mycotoxin level with regard to corn borers and Fusarium mycoflora in maize (Zea mays L.) fields. Crop Prot. 28:302-308.

7. Glaab, J., and Kaiser, W. M. 1999. Increased nitrate reductase activity in leaf tissue after application of the fungicide kresoxim-methyl. Planta 207:442-448.

8. Grossman, K., Kwistkowski, J., and Caspar, G. 1999. Regulation of phytohormone levels, leaf senescence and transpiration by the strobilurin kresoxim-methyl in wheat (Triticum aestivum). J. Plant Physiol. 154:805-808.

9. Grossmann, K., and Retzlaff, G. 1997. Bioregulatory effects of the fungicidal strobilurin kresoxim-methyl in wheat (Triticum aestivum). Pestic. Sci. 50:11-20.

10. Hanway, J. J. 1969. Defoliation effects on different corn (Zea mays L.) hybrids as influenced by plant population and stage of development. Agron. J. 61:534-538.

11. Hicks, D. R., Nelson, W. W., and Ford, J. H. 1977. Defoliation effects on corn hybrids 
adapted to the northern corn belt. Agron. J. 69:387-390.

12. Lauer, J. G., Roth, G. W., and Bertram, M. G. 2004. Impact of defoliation on corn forage yield. Agron. J. 96:1459-1463.

13. Munkvold, G. P., Doerge, T., and Bradley, C. 2008. IPM is still alive for corn leaf diseases: look before you spray. In: Proc. 62nd Annu. Corn Sorghum Res. Conf. Chicago. CD-ROM, American Seed Trade Association, Alexandria, VA.

14. Munkvold, G. P., Martinson, C. A., Shriver, J. M., and Dixon, P. M. 2001. Probabilities for profitable fungicide use against gray leaf spot in hybrid maize. Phytopathology 91:477-484.

15. National Crop Insurance Services. 1998. Corn loss adjustment handbook. National Crop Insurance Service, Overland Park, KS.

16. Pataky, J. K., and Eastburn, D. M. 1993. Comparing partial resistance to Puccinia sorghi and application of fungicides for controlling common rust on sweet corn. Phytopathology 83:1046-1051.

17. Paul, P. A., and Munkvold, G. P. 2004. A model-based approach to preplanting risk assessment for gray leaf spot of maize. Phytopathology 94:1350-1357.

18. Roth, G. W., and Lauer, J. G. 2008. Impact of defoliation on corn forage quality. Agron. J. 100:651-657.

19. Ruske, R. E., Gooding, M. J., and Jones, S. A. 2003. The effects of triazole and strobilurin fungicide programmes on nitrogen uptake, partitioning, remobilization and grain $\mathrm{N}$ accumulation in winter wheat cultivars. J. Agric. Sci. 140:395-407.

20. Shapiro, C. A., Peterson, T. A., and Flowerday, A. D. 1986. Yield loss due to simulated hail damage on corn: a comparison of actual and predicted yields. Agron. J. 78:585-589.

21. Vasilas, B. L., and Seif, R. D. 1985. Defoliation effects on two corn inbreds and their single-cross hybrid. Agron. J. 77:816-820.

22. Ward, J. M. J., Laing, M. D., and Nowell, D. C. 1997. Chemical control of maize grey leaf spot. Crop Prot. 16:265-271.

23. Ward, J. M. J. Laing, M. D., and Rijkenberg, F. H. J. 1997. Frequency and timing of fungicide applications for the control of gray leaf spot in maize. Plant Dis. 81:41-48.

24. Wegulo, S. N., Martinson, C. A., Rivera-C., J. M., and Nutter, F. W., Jr. 1997. Model for economic analysis of fungicide usage in hybrid corn seed production. Plant Dis. 81:415-422.

25. White, D. G. 1999. Fungal stalk rots. Pages 38-43 in: Compendium of Corn Diseases, 3rd ed. D. G. White, ed. American Phytopathological Society, St. Paul, MN.

26. Wu, Y. X., and von Tiedemann, A. 2001. Physiological effects of azoxystrobin and epoxiconazole on senescence and oxidative status of wheat. Pestic. Biochem. Physiol 71:1-10.

27. Wu, Y. X., and von Tiedemann, A. 2002. Impact of fungicides on active oxygen species and antioxidant enzymes in spring barley (Hordeum vulgare L.) exposed to ozone. Environ. Pollut. 116:37-47.

28. Ypema, H. L., and Gold, R. E. 1999. Kresoxim-methyl: modification of a naturally occurring compound to produce a new fungicide. Plant Dis. 83:4-19. 